\title{
Mechanism of oxidation of L-methionine by iron(III)-1,10-phenanthroline complex - A kinetic study
}

\author{
P VANI $^{* 1}, \mathrm{~K}_{\text {KRISHNA KISHORE }}{ }^{1}, \mathrm{R}^{\mathrm{RAMBABU}}{ }^{2}$ and \\ L S A DIKSHITULU ${ }^{2}$ \\ ${ }^{1}$ Department of Inorganic and Analytical Chemistry, School of Chemistry, \\ Andhra University, Visakhapatnam 530 003, India \\ ${ }^{2}$ Gayatri Engineering College, Madurawada, Visakhapatnam 530 041, India \\ e-mail: vani_chem.@yahoo.co.in
}

MS received 19 May 2001; revised 2 July 2001

\begin{abstract}
Kinetics and mechanism of oxidation of L-methionine by iron(III)-1,10phenanthroline complex have been studied in perchloric acid medium. The reaction is first order each in iron(III) and methionine. Increase in [phenanthroline] increases the rate while increase in $\left[\mathrm{HClO}_{4}\right]$ decreases it. While the reactive species of the substrate is the zwitterionic form, that of the oxidant is $\left[\mathrm{Fe}(\mathrm{phen})_{2}\left(\mathrm{H}_{2} \mathrm{O}\right)_{2}\right]^{3+}$. The proposed
\end{abstract} mechanism leads to the rate law

$$
\frac{\mathrm{d}\left[\mathrm{Fe}(\text { phen })_{3}^{2+}\right]}{\mathrm{d} t}=\frac{k_{2} K_{4} K_{3} K_{2}^{2}[\mathrm{Fe}}{\left(1+K_{1}\left[\mathrm{H}^{+}\right]\right)\left(\left[\mathrm{H}^{+}\right]^{2}+K_{4} K_{3} K_{2}^{2}[\text { phen }]^{2}\right)} \text {. }
$$

Keywords. Oxidation of methionine; iron(III)-phenanthroline complex.

\section{Introduction}

In continuation of our studies on the oxidation of methionine ${ }^{1-3}$, one of the sulphurcontaining essential amino acids, we now report the mechanism of its oxidation in $\mathrm{HClO}_{4}$ medium by iron(III)-1,10-phenanthroline complex. It is interesting to note that while the protonated form of methionine was observed to be the reactive species in the manganese (III) ${ }^{1}$ and bromate ${ }^{2}$ oxidations, the zwitterionic form was found to be the active species in the oxidations by iron(III) in presence of $2,2^{\prime}$-bipyridyl ${ }^{3}$ or 1,10 -phenanthroline. While both phenanthroline and bipyridyl form similar complexes with iron(III), the oxidation of methionine with iron(III)-phenanthroline complex is much faster compared to iron(III)2,2'-bipyridyl. Further, the kinetics of oxidation of methionine with iron(III)phenanthroline complex is studied in aqueous perchloric acid medium, unlike its oxidation with iron(III)-2,2'-bipyridyl which was carried out in presence of methanol.

\section{Experimental}

\subsection{Preparation of solutions}

A $0.2 \mathrm{~mol} \mathrm{dm}^{-3}$ solution of L-methionine was prepared by dissolving L-methionine (Sarabhai Merck) in distilled water and its strength determined by the iodimetric

*For correspondence 
method ${ }^{4}$. Iron(III) perchlorate solution was prepared by heating iron wire (E Merck, Pro Analysi grade) with concentrated perchloric acid. The moist solid thus obtained was dissolved in distilled water and a sufficient quantity of $\mathrm{HClO}_{4}$ was added to prevent the hydrolysis of iron(III). The iron(III) content was determined by titrating it with EDTA using variamine blue B as indicator. The free acid present in iron(III) stock solution was determined by titrating with $\mathrm{NaOH}$ using phenolphthalein as indicator according to the method of Milburn et $a l^{5}$. A fresh $0.015 \mathrm{~mol} \mathrm{dm}^{-3}$ solution of 1,10-phenanthroline was prepared by dissolving 1,10-phenanthroline (E Merck) in distilled water.

\subsection{Kinetics procedure}

The kinetic measurements were carried out at $50 \pm 0.1^{\circ} \mathrm{C}$ in $0.06 \mathrm{~mol} \mathrm{dm}^{-3}$ perchloric acid medium under the conditions [methionine] [phen] [iron(III)]. Since methionine and phenanthroline get protonated in acid medium, $\left[\mathrm{H}^{+}\right]$does not remain constant as the concentrations of these two species are altered in the kinetic runs. $\left[\mathrm{H}^{+}\right]$of the reaction mixture is therefore adjusted to the desired value in a trial run using dilute perchloric acid. The actual runs are then carried out duplicating these conditions in the reaction mixtures. The progress of the reaction is followed by measuring the absorbance of tris-phenanthroline iron(II) formed at $510 \mathrm{~nm}$, using a Shimadzu double beam spectrophotometer UV-140 (Japan) with $1 \mathrm{~cm}$ cells. The temperature was kept constant using a SEW Lab liquid circulatory bath S-36. Rate constants were found to be reproducible within $\pm 4 \%$.

\section{Results and discussion}

\subsection{Stoichiometry}

Known amounts of methionine were reacted completely with a known excess of iron(III) at $50^{\circ} \mathrm{C}$ in $0.06 \mathrm{~mol} \mathrm{dm}^{-3} \mathrm{HClO}_{4}$ in presence of excess of phenanthroline. The stoichiometry of the reaction was found to correspond to the equation.

$$
\begin{aligned}
& \mathrm{CH}_{3} \mathrm{SCH}_{2} \mathrm{CH}_{2} \mathrm{CH}\left(\stackrel{+}{\mathrm{N}_{3}}\right) \mathrm{COO}^{-}+2\left[\mathrm{Fe}(\text { phen })_{2}\left(\mathrm{H}_{2} \mathrm{O}\right)_{2}\right]^{3+} \\
& \left.\stackrel{\text { excess of phen }}{\longrightarrow} \mathrm{CH}_{3} \prod_{\mathrm{SCH}} \mathrm{CH}_{2} \mathrm{CH} \stackrel{+}{\mathrm{NH}_{3}}\right) \mathrm{COO}^{-}+2\left[\mathrm{Fe}(\text { phen })_{3}\right]^{2+} .
\end{aligned}
$$

\subsection{Product analysis}

Product analysis was carried out by taking the reaction mixture containing $5.0 \times$ $10^{-2} \mathrm{~mol} \mathrm{dm}^{-3}$ methionine, $6.0 \times 10^{-2} \mathrm{~mol} \mathrm{dm}^{-3} \quad \mathrm{HClO}_{4}, \quad 6.0 \times 10^{-3} \mathrm{~mol} \mathrm{dm}^{-3}$ phenanthroline and $8.0 \times 10^{-5} \mathrm{~mol} \mathrm{dm}^{-3}$ iron(III), in $50 \mathrm{~cm}^{3}$ solution, and allowing it to stand for $2 \mathrm{~h}$ at $50^{\circ} \mathrm{C}$. Thereafter $10 \mathrm{~cm}^{3}$ of $0.4 \mathrm{~mol} \mathrm{dm}^{-3}$ sodium bicarbonate was added and the solution stirred vigorously, followed by dropwise addition of benzoyl chloride solution until precipitation was complete. The precipitate obtained was identified as $\mathrm{N}$ benzoyl methionine sulphoxide (m.p. $183^{\circ} \mathrm{C}$ ), a derivative of methionine sulphoxide ${ }^{6}$. 
Table 1. Effect of $\left[\mathrm{Fe}^{\mathrm{III}}\right]$, [Met], [phen], $\left[\mathrm{H}^{+}\right]$and ionic strength $(\mu)$ on the pseudofirst-order rate constant, $k^{\prime}$, at $50 \pm 0 \cdot 1^{\circ} \mathrm{C}$.

\begin{tabular}{cccccc}
\hline $\begin{array}{c}{\left[\mathrm{Fe}^{\mathrm{III}}\right] \times 10^{5}} \\
\left(\mathrm{~mol} \mathrm{dm}^{-3}\right)\end{array}$ & $\begin{array}{c}{[\mathrm{Met}] \times 10^{2}} \\
\left(\mathrm{~mol} \mathrm{dm}^{-3}\right)\end{array}$ & $\begin{array}{c}{[\mathrm{Phen}] \times 10^{3}} \\
\left.(\mathrm{~mol} \mathrm{dm})^{-3}\right)\end{array}$ & $\begin{array}{c}{\left[\mathrm{H}^{+}\right] \times 10^{2}} \\
\left(\mathrm{~mol} \mathrm{dm}^{-3}\right)\end{array}$ & $\begin{array}{c}\mu \\
\left(\mathrm{mol} \mathrm{dm}^{-3}\right)\end{array}$ & $\begin{array}{c}k^{\prime} \times 10^{4} \\
\left(s^{-1}\right)\end{array}$ \\
\hline $5 \cdot 0$ & $5 \cdot 0$ & $6 \cdot 0$ & $6 \cdot 0$ & $0 \cdot 12$ & $1 \cdot 54$ \\
$6 \cdot 0$ & $5 \cdot 0$ & $6 \cdot 0$ & $6 \cdot 0$ & $0 \cdot 12$ & $1 \cdot 58$ \\
$8 \cdot 0$ & $5 \cdot 0$ & $6 \cdot 0$ & $6 \cdot 0$ & $0 \cdot 12$ & $1 \cdot 60$ \\
$9 \cdot 0$ & $5 \cdot 0$ & $6 \cdot 0$ & $6 \cdot 0$ & $0 \cdot 12$ & $1 \cdot 54$ \\
$10 \cdot 0$ & $5 \cdot 0$ & $6 \cdot 0$ & $6 \cdot 0$ & $0 \cdot 12$ & $1 \cdot 49$ \\
$8 \cdot 0$ & $2 \cdot 0$ & $6 \cdot 0$ & $6 \cdot 0$ & $0 \cdot 12$ & $0 \cdot 82$ \\
$8 \cdot 0$ & $3 \cdot 0$ & $6 \cdot 0$ & $6 \cdot 0$ & $0 \cdot 12$ & $1 \cdot 15$ \\
$8 \cdot 0$ & $4 \cdot 0$ & $6 \cdot 0$ & $6 \cdot 0$ & $0 \cdot 12$ & $1 \cdot 48$ \\
$8 \cdot 0$ & $5 \cdot 0$ & $6 \cdot 0$ & $6 \cdot 0$ & $0 \cdot 12$ & $1 \cdot 63$ \\
$8 \cdot 0$ & $6 \cdot 0$ & $6 \cdot 0$ & $6 \cdot 0$ & $0 \cdot 12$ & $2 \cdot 20$ \\
$8 \cdot 0$ & $5 \cdot 0$ & $6 \cdot 0$ & $1 \cdot 0$ & $0 \cdot 12$ & $11 \cdot 26$ \\
$8 \cdot 0$ & $5 \cdot 0$ & $6 \cdot 0$ & $3 \cdot 0$ & $0 \cdot 12$ & $5 \cdot 88$ \\
$8 \cdot 0$ & $5 \cdot 0$ & $6 \cdot 0$ & $4 \cdot 0$ & $0 \cdot 12$ & $3 \cdot 26$ \\
$8 \cdot 0$ & $5 \cdot 0$ & $6 \cdot 0$ & $5 \cdot 0$ & $0 \cdot 12$ & $2 \cdot 30$ \\
$8 \cdot 0$ & $5 \cdot 0$ & $6 \cdot 0$ & $6 \cdot 0$ & $0 \cdot 12$ & $1 \cdot 63$ \\
$8 \cdot 0$ & $5 \cdot 0$ & $6 \cdot 0$ & $6 \cdot 0$ & $0 \cdot 15$ & $1 \cdot 65$ \\
$8 \cdot 0$ & $5 \cdot 0$ & $6 \cdot 0$ & $6 \cdot 0$ & $0 \cdot 17$ & $1 \cdot 60$ \\
$8 \cdot 0$ & $5 \cdot 0$ & $6 \cdot 0$ & $6 \cdot 0$ & $0 \cdot 20$ & $1 \cdot 58$ \\
$8 \cdot 0$ & $5 \cdot 0$ & $6 \cdot 0$ & $6 \cdot 0$ & $0 \cdot 22$ & $1 \cdot 62$ \\
$8 \cdot 0$ & $5 \cdot 0$ & $2 \cdot 0$ & $6 \cdot 0$ & $0 \cdot 12$ & $0 \cdot 25$ \\
$8 \cdot 0$ & $5 \cdot 0$ & $3 \cdot 0$ & $6 \cdot 0$ & $0 \cdot 12$ & $0 \cdot 52$ \\
$8 \cdot 0$ & $5 \cdot 0$ & $4 \cdot 0$ & $6 \cdot 0$ & $0 \cdot 12$ & $0 \cdot 85$ \\
$8 \cdot 0$ & $5 \cdot 0$ & $8 \cdot 0$ & $6 \cdot 0$ & $0 \cdot 12$ & $2 \cdot 27$ \\
8.0 & $5 \cdot 0$ & $9 \cdot 0$ & $6 \cdot 0$ & $0 \cdot 12$ & $2 \cdot 77$ \\
\hline
\end{tabular}

\subsection{Product dependence}

Iron(II) was found to have no effect on the rate of the reaction.

\subsection{Iron(III) dependence}

When the kinetic runs were made with isolation of iron(III) by taking methionine in excess, plots of $\log \left(A_{\alpha}-A_{t}\right)$ versus time were found to be linear up to $75 \%$ of the reaction, indicating unit order with respect to iron(III). Furthermore, when $\left[\mathrm{Fe}^{\mathrm{III}}\right]$ was varied from $5 \cdot 0-10 \cdot 0 \times 10^{-5} \mathrm{~mol} \mathrm{dm}^{-3}$ (table 1) the pseudo-first order rate constants remained constant, confirming first order dependence on $\left[\mathrm{Fe}^{\mathrm{III}}\right]$.

\subsection{Methionine dependence}

Reaction order with respect to methionine was determined by carrying out kinetic runs in $0.06 \mathrm{~mol} \mathrm{dm}^{-3} \mathrm{HClO}_{4}$ in the presence of $0.006 \mathrm{~mol} \mathrm{dm}^{-3}$ phenanthroline and varying the methionine concentration over the $2 \cdot 0-6 \cdot 0 \times 10^{-2} \mathrm{~mol} \mathrm{dm}^{-3}$ range. Results thus obtained (table 1) show that the pseudo-first order rate constant, $k^{\prime}$, increases with increasing [methionine]. Further, the plot of $k^{\prime}$ versus [methionine] is a straight line passing through the origin, confirming first-order dependence on [methionine]. 


\subsection{Hydrogen ion dependence}

In order to study the effect of $\left[\mathrm{H}^{+}\right]$on the pseudo-first order rate constant, $k^{\prime}$, kinetic runs were carried out at various $\mathrm{HClO}_{4}$ concentrations over $1.0-6.0 \times 10^{-2} \mathrm{~mol} \mathrm{dm}^{-3}$ range, keeping ionic strength and other reactant concentrations constant. The rate constants were found to decrease with increase in acid concentration (table 1).

\subsection{Ionic strength dependence}

The effect of ionic strength on the pseudo-first order rate constant, $k^{\prime}$, was studied over the $0 \cdot 12-0 \cdot 22 \mathrm{~mol} \mathrm{dm}^{-3}$ range using $\mathrm{NaClO}_{4}$, keeping the concentrations of all other species in the reaction mixture constant. The results recorded in table 1 show that the rate is independent of ionic strength.

\subsection{Dependence on [phenanthroline]}

Effect of phenanthroline on the pseudo-first order rate constant, $k^{\prime}$, was studied at $50^{\circ} \mathrm{C}$ by varying the 1,10 -phenanthroline concentration from $2.0 \times 10^{-3}$ to $9.0 \times 10^{-3} \mathrm{~mol} \mathrm{dm}^{-3}$ keeping all other reactant concentrations constant. Rate increases with increase in phenanthroline concentration. Furthermore, plots of $1 / k^{\prime}$ versus $1 /[\text { phen }]^{2}$ were linear with positive intercepts on the $1 / k^{\prime}$ axis. This suggests a Michaelis-Menten type of behaviour, with the formation of a $1: 2$ complex between iron(III) and 1,10-phenanthroline.

\subsection{Thermodynamic parameters}

Activation parameters were determined from the $k^{\prime}$ values obtained at the temperatures 45,50 and $55^{\circ} \mathrm{C}$ (table 2) keeping the concentrations of all other ions constant: $[$ Met $]=5.0 \times 10^{-2} \mathrm{~mol} \mathrm{dm}^{-3} ; \quad\left[\mathrm{Fe}^{\mathrm{III}}\right]=8.0 \times 10^{-5} \mathrm{~mol} \mathrm{dm}^{-3} ; \quad\left[\mathrm{H}^{+}\right]=6.0 \times 10^{-2} \mathrm{~mol} \mathrm{dm}^{-3}$; $\mu=0.12 \mathrm{~mol} \mathrm{dm}^{-3}\left(\mathrm{NaClO}_{4}\right)$. The energy of activation $\mathrm{Ea}$, and the entropy of activation $\Delta S^{\ddagger}$ were calculated employing the linear least squares method and were $106 \cdot 4 \pm 9.2 \mathrm{~kJ} \mathrm{~mol}^{-1}$ and $28.5 \pm 28.5 \mathrm{~J} \mathrm{~K}^{-1} \mathrm{~mol}^{-1}$ respectively.

Phenanthroline has a $p K a$ value of 4.641 at $50^{\circ} \mathrm{C}$ and in the $\left[\mathrm{H}^{+}\right]$range investigated, phenanthroline exists mainly in the form of $\operatorname{Hphen}^{+}(>98 \%)$. Baxendale and Bridge ${ }^{7}$ reported that a yellow complex is formed when iron(III) is mixed with 1,10phenanthroline or 2,2'-bipyridyl and from a photometric study of the complex, concluded that the species has the formula $\left[\mathrm{Fe}(\mathrm{phen})_{n}\right]^{3+}$, the maximum value of $n$ being 2.5 at very high phenanthroline concentrations. Baxendale ${ }^{8}$ carried out a photometric study of the brown complex formed by direct mixing of iron(III) and phenanthroline in aqueous

Table 2. Effect of temperature on the pseudofirst order rate constant, $k^{\prime}$. $\left[\mathrm{Fe}^{\mathrm{III}}\right]=8 \cdot 0 \times$ $10^{-5} \mathrm{~mol} \mathrm{dm}^{-3}$; $\quad\left[\right.$ Met] $=5.0 \times 10^{-2} \mathrm{~mol} \mathrm{dm}^{-3}$; [phen $]=6.0 \times 10^{-3} \mathrm{~mol} \mathrm{dm}^{-3} ; \quad\left[\mathrm{H}^{+}\right]=6.0 \times 10^{-2}$ mol dm ${ }^{-3} ; \mu=0.12 \mathrm{~mol} \mathrm{dm}^{-3}\left(\mathrm{NaClO}_{4}\right)$.

\begin{tabular}{llll}
\hline Temperature & 318 & 323 & 328 \\
\hline$k^{\prime} \times 10^{4}\left(\mathrm{~s}^{-1}\right)$ & 0.77 & 1.58 & 2.63 \\
\hline
\end{tabular}


solution and stated that the formula of the complex is probably $\left[\mathrm{Fe}(\mathrm{phen})_{2}\right]^{3+}$. Subsequently, considerable attention was paid to the elucidation of the structures of these brown complexes of iron(III) with 2,2'-bipyridyl and 1,10-phenanthroline. David and de Mello ${ }^{9}$ established the formation of $\left[\mathrm{FeL}_{2}\left(\mathrm{H}_{2} \mathrm{O}\right)_{2}\right]^{3+}$ from the interaction of the binuclear species with $\mathrm{H}^{+}$ions. In view of these reports, the formula of the iron(III)-1,10phenanthroline complex in the present study may be considered to be $\left[\mathrm{Fe}(\text { phen })_{2}\left(\mathrm{H}_{2} \mathrm{O}\right)_{2}\right]^{3+}$. This complex is different from tris-1,10-phenanthroline iron(III), $\left.[\mathrm{Fe} \text { (phen })_{3}{ }^{3+}\right]$, which is a blue compound that can only be prepared by the oxidation of the corresponding iron(II) complex ${ }^{10}$. While the blue complex is substitution inert (spinpaired), the yellow-brown complex formed by direct mixing of iron(III) and phenanthroline is labile (spin free).

All amino acids possess minimum two $p K$ values, one corresponding to the carboxylic acid group $\left(p K_{1}=2 \cdot 0\right)$ and the other to the amino group $\left(p K_{2}=10 \cdot 0\right)$. Since methionine is a sulphur-containing amino acid, under the present experimental conditions $\left\{\left[\mathrm{H}^{+}\right]=6 \cdot 0 \times 10^{-2} \mathrm{~mol} \mathrm{dm}^{-3}\right\}$ it exists in the form of the protonated species $\mathrm{H}_{3} \mathrm{CSCH}_{2} \mathrm{CH}_{2} \mathrm{CH}\left(\mathrm{NH}_{3}\right) \mathrm{COOH}(\mathrm{HMet})$ to the extent of $85 \%$, the remaining $15 \%$ being present in the zwitterionic form, $\mathrm{H}_{3} \mathrm{CSCH}_{2} \mathrm{CH}_{2} \mathrm{CH}\left(\mathrm{N}_{3}\right) \mathrm{COO}^{-}\left(\mathrm{Met}_{z}\right)$. Based on these observations, the following mechanism has been proposed.

$$
\begin{aligned}
& \mathrm{R}-\mathrm{S}-\mathrm{CH}_{3}\left(\mathrm{Met}_{z}\right)+\mathrm{H}^{+} \quad \square^{K_{1}} \mathrm{HR}-\mathrm{S}-\mathrm{CH}_{3}, \\
& \text { Hphen }^{+} \quad \square^{K_{2}} \text { phen }+\mathrm{H}^{+} \text {, } \\
& \mathrm{Fe}^{\mathrm{III}}+\text { phen } \quad \square^{K_{3}} \mathrm{Fe}(\text { phen })^{3+}\left(\mathrm{C}_{1}\right), \\
& \mathrm{C}_{1} \text { + phen } \quad \square^{K_{4}} \mathrm{Fe}(\text { phen })_{2}{ }^{3+}\left(\mathrm{C}_{2}\right),
\end{aligned}
$$

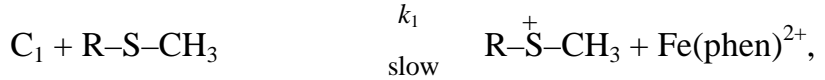

$$
\begin{aligned}
& \mathrm{C}_{2}+\mathrm{R}-\mathrm{S}-\mathrm{CH}_{3} \quad \mathrm{G}_{\mathrm{n}}^{\mathrm{k}} \mathrm{\textrm {w }}-\stackrel{+}{\mathrm{S}}-\mathrm{CH}_{3}+\mathrm{Fe}(\text { phen })_{2}{ }^{2+}, \\
& \mathrm{C}_{1}+\mathrm{HR}-\mathrm{S}-\mathrm{CH}_{3}(\mathrm{HMet}) \quad \underset{\text { slow }}{\Gamma_{3}^{k_{3}}} \mathrm{HR}-\stackrel{+}{\mathrm{S}}-\mathrm{CH}_{3}+\mathrm{Fe}(\text { phen })_{2}{ }^{2+}, \\
& \mathrm{C}_{2}+\mathrm{HR}-\mathrm{S}-\mathrm{CH}_{3}(\text { Hmet }) \quad\left[\begin{array}{l}
k_{4} \\
\mathrm{H}
\end{array} \mathrm{w} \text {, HR }-\stackrel{+}{\mathrm{S}}-\mathrm{CH}_{3}+\mathrm{Fe}(\text { phen })_{2}{ }^{2+}\right. \text {, } \\
& \mathrm{C}_{1}+\mathrm{R}-\stackrel{+}{\mathrm{S}}-\mathrm{CH}_{3} \stackrel{\text { fast }}{\square} \text { products, } \\
& \mathrm{C}_{2}+\mathrm{R}-\stackrel{+}{\mathrm{S}}-\mathrm{CH}_{3} \quad \stackrel{\text { fast }}{\square} \text { products, } \\
& \mathrm{C}_{1}+\mathrm{HR}-\stackrel{+}{\mathrm{S}}-\mathrm{CH}_{3} \stackrel{\text { fast }}{\square} \text { products, }
\end{aligned}
$$




$$
\begin{gathered}
\text { fast } \text { products, } \\
\mathrm{Fe}(\text { phen })^{2+} \text { or } \mathrm{Fe}(\text { phen })_{2}{ }^{2+}+\text { phen } \quad \stackrel{\text { fast }}{\square} \mathrm{Fe}(\text { phen })_{3}{ }^{3+},
\end{gathered}
$$

where $\mathrm{R}=-\mathrm{CH}_{2} \mathrm{CH}_{2} \mathrm{CH}\left(\stackrel{+}{\mathrm{N}} \mathrm{H}_{3}\right) \mathrm{COO}^{-}$and $\mathrm{HR}$ is its protonated form, $-\mathrm{CH}_{2} \mathrm{CH}_{2} \mathrm{CH}\left(\mathrm{NH}_{3}\right) \mathrm{COOH}, \mathrm{Me}_{\mathrm{z}}$ is the zwitterionic form and HMet is its protonated form.

$$
\begin{aligned}
& \text { Rate }= \frac{\mathrm{d}\left[\mathrm{Fe}(\mathrm{phe}) 3_{3}^{2+}\right.}{\mathrm{d} t}=k_{1}\left[\mathrm{C}_{1}\right]\left[\mathrm{Met}_{\mathrm{z}}\right]+k_{2}\left[\mathrm{C}_{2}\right]\left[\mathrm{Met}_{\mathrm{z}}\right]+k_{3}\left[\mathrm{C}_{1}\right][\mathrm{HMet}] \\
&+k_{4}\left[\mathrm{C}_{2}\right][\mathrm{HMet}] \\
&=\left\{k_{1}\left[\mathrm{Met}_{z}\right]+k_{3}[\mathrm{HMet}]\right\}\left[\mathrm{C}_{1}\right]+\left\{k_{2}\left[\mathrm{Met}_{z}\right]+k_{4}[\mathrm{HMet}]\right\}\left(\mathrm{C}_{2}\right),
\end{aligned}
$$

where

$$
\begin{aligned}
& {\left[\mathrm{C}_{1}\right]=K_{3} K_{2}\left[\mathrm{Fe}^{\mathrm{III}}\right]_{e}\left[\mathrm{Hphen}^{+}\right]_{e} /\left[\mathrm{H}^{+}\right]_{e},} \\
& {\left[\mathrm{C}_{2}\right]=K_{4} K_{3} K_{2}^{2}\left[\mathrm{Fe}^{\mathrm{III}}\right]_{e}\left[\mathrm{Hphen}^{+}\right]^{2} /\left[\mathrm{H}^{+}\right]_{e}^{2},}
\end{aligned}
$$

and

$$
\left[\mathrm{Fe}^{\mathrm{III}}\right]_{t}=\left[\mathrm{Fe}^{\mathrm{III}}\right]_{e}+\left[\mathrm{C}_{1}\right]+\left[\mathrm{C}_{2}\right] .
$$

Substituting for $\left[\mathrm{C}_{1}\right]$ and $\left[\mathrm{C}_{2}\right]$ from (16) and (17) in (18)

$$
\begin{gathered}
{\left[\mathrm{Fe}^{\mathrm{III}}\right]_{e}=\left[\mathrm{H}^{+}\right]_{e}^{2}\left[\mathrm{Fe}^{\mathrm{III}}\right]_{t} /\left[\mathrm{H}^{+}\right]_{e}^{2}+K_{3} K_{2}\left[\mathrm{Hphen}^{+}\right]_{e}\left[\mathrm{H}^{+}\right]_{e}} \\
+K_{4} K_{3} K_{2}^{2}\left[\mathrm{Hphen}^{+}\right]_{e}^{2} .
\end{gathered}
$$

Substituting for $\left[\mathrm{Fe}^{\mathrm{III}}\right]_{e}$ from (19) in (16) and (17) leads to

$$
\begin{aligned}
{\left[\mathrm{C}_{1}\right]=K_{3} K_{2}\left[\mathrm{H}^{+}\right]_{e}\left[\mathrm{Fe}^{\mathrm{III}}\right]_{t}\left[\mathrm{Hphen}^{+}\right]_{e} /\left[\mathrm{H}^{+}\right]_{e}^{2} } & \\
& +K_{3} K_{2}\left[\mathrm{Hphen}^{+}\right]_{e}\left[\mathrm{H}^{+}\right]_{e}+K_{4} K_{3} K_{2}^{2}\left[\mathrm{Hphen}^{+}\right]_{e}^{2},
\end{aligned}
$$

and

$$
\begin{aligned}
{\left[\mathrm{C}_{2}\right]=K_{4} K_{3} K_{2}^{2}\left[\mathrm{Fe}^{\mathrm{III}}\right]_{t}\left[\mathrm{Hphen}^{+}\right]_{e}{ }^{2} /\left[\mathrm{H}^{+}\right]_{e}{ }^{2} } & \\
& +K_{3} K_{2}\left[\mathrm{Hphen}^{+}\right]_{e}\left[\mathrm{H}^{+}\right]_{e}+K_{4} K_{3} K_{2}^{2}\left[\text { Hphen }^{+}\right]_{e}{ }^{2} .
\end{aligned}
$$

Similarly,

$$
[\mathrm{Met}]_{t}=\left[\mathrm{Met}_{z}\right]+[\mathrm{HMet}]
$$

and from (1), 


$$
\begin{aligned}
& {\left[\mathrm{Met}_{z}\right]=[\mathrm{Met}]_{t} / 1+K_{1}\left[\mathrm{H}^{+}\right]_{e},} \\
& \text { and }[\mathrm{HMet}]=K_{1}\left[\mathrm{H}^{+}\right]_{e}[\mathrm{Met}]_{t} / 1+K_{1}\left[\mathrm{H}^{+}\right]_{e} .
\end{aligned}
$$

Finally, substituting for $\left[\mathrm{C}_{1}\right],\left[\mathrm{C}_{2}\right],\left[\mathrm{Met}_{z}\right]$ and $[\mathrm{HMet}]$ from (16), (17) and (24) in (15) we get

$$
\begin{aligned}
& \text { rate }=\frac{-\mathrm{d}\left[\mathrm{Fe}^{\mathrm{III}}\right]}{\mathrm{d} t} \\
& =\frac{\left\{\left(k_{1}+k_{3} K_{1}\left[\mathrm{H}^{+}\right]_{e}\right) K_{3} K_{2}\left[\mathrm{H}^{+}\right]_{e}+\left(k_{2}+k_{4} K_{1}\left[\mathrm{H}^{+}\right]_{e}\right) K_{4} K_{3} K_{2}^{2}\left[\mathrm{Hphen}^{+}\right]\right\}\left[\mathrm{Fe}^{\mathrm{III}}\right]_{t}\left[\mathrm{Hphen}^{+}\right][\mathrm{Met}]_{t}}{\left\{1+K_{1}\left[\mathrm{H}^{+}\right]_{e}\right\}\left\{\left[\mathrm{H}^{+}\right]_{e}^{2}+K_{3} K_{2}\left[\mathrm{Hphen}^{+}\right]_{e}\left[\mathrm{H}^{+}\right]_{e}+K_{4} K_{3} K_{2}^{2}\left[\mathrm{Hphen}^{+}\right]_{e}^{2}\right\}} .
\end{aligned}
$$

Since the concentrations of phenanthroline and hydrogen ion are large compared to that of iron(III), $\left[\mathrm{Hphen}^{+}\right]_{e}=[\mathrm{phen}]_{t}$ and $\left[\mathrm{H}^{+}\right]_{e}=\left[\mathrm{H}^{+}\right]_{t}$, Equation (25), therefore, reduces to the form,

$$
\text { rate }=\frac{\left\{\left(k_{1}+k_{3} K_{1}\left[\mathrm{H}^{+}\right]\right) K_{3} K_{2}\left[\mathrm{H}^{+}\right]+\left(k_{2}+k_{4} K_{1}\left[\mathrm{H}^{+}\right]\right) K_{4} K_{3} K_{2}^{2}[\text { phen }]\right\}\left[\mathrm{Fe}^{\mathrm{III}}\right]_{t}[\text { phen }]_{t}[\mathrm{Met}]}{\left\{1+K_{1}\left[\mathrm{H}^{+}\right]\right\}\left\{\left[\mathrm{H}^{+}\right]^{2}+K_{3} K_{2}[\text { phen }]\left[\mathrm{H}^{+}\right]+K_{4} K_{3} K_{2}^{2}[\text { phen }]^{2}\right\}} .
$$

Ionic strength has negligible effect on the rate of the reaction, but increase in $\left[\mathrm{H}^{+}\right]$has considerable retarding effect. Since the $[\mathrm{phen}]_{e}$ is not significantly altered in the $\left[\mathrm{H}^{+}\right]$ range studied, retardation by the $\left[\mathrm{H}^{+}\right]$may be mainly attributed to the conversion of the more reactive neutral species of methionine into the far less reactive protonated form. In view of this, $k_{3}$ and $k_{4}$ may be presumed to be far less than $k_{1}$ and $k_{2}$ respectively. Hence, $k_{3} K_{1}\left[\mathrm{H}^{+}\right]$and $k_{4} K_{1}\left[\mathrm{H}^{+}\right]$may be neglected in comparison with $k_{1}$ and $k_{2}$ respectively in the numerator of (26). Therefore, the rate equation reduces to

$$
\text { rate }=\frac{K_{3} K_{2}\left[\mathrm{Fe}^{\mathrm{III}}\right][\text { phen }][\mathrm{Met}]\left(k_{1}\left[\mathrm{H}^{+}\right]+k_{2} K_{4} K_{2}[\text { phen }]\right)}{\left(1+K_{1}\left[\mathrm{H}^{+}\right]\right)\left(\left[\mathrm{H}^{+}\right]^{2}+K_{3} K_{2}[\text { phen }]\left[\mathrm{H}^{+}\right]+K_{4} K_{3} K_{2}^{2}[\text { phen }]^{2}\right)} .
$$

The rate equation explains the observed first order with respect to iron(III) and methionine, as well as the increase in rate with [phen] and decrease in rate with $\left[\mathrm{H}^{+}\right]$. But this equation does not predict any simple graphical relationship between the observed rate constant, $k^{1}\left(\mathrm{rate} /\left[\mathrm{Fe}^{\mathrm{III}}\right]\right)$ and either $\left[\mathrm{H}^{+}\right]$or [phen]. However, our experimental results indicate that the plot of $1 / k^{\prime}$ versus $1 /[\mathrm{phen}]^{2}$ is linear with a positive intercept on the rate axis. Such a plot may be expected from the rate equation if only the terms $k_{1}\left[\mathrm{H}^{+}\right]$in the numerator and $K_{3} K_{2}\left[\mathrm{H}^{+}\right][\mathrm{phen}]$ in the denominator are neglected. In such a case, the rate equation reduces to

$$
\frac{-\mathrm{d}\left[\mathrm{Fe}\left(\mathrm{phen}_{3}^{2+}\right]\right.}{\mathrm{d} t}=\frac{k_{2} K_{4} K_{3} K_{2}^{2}\left[\mathrm{Fe}{ }^{\mathrm{III}}\right][\mathrm{phen}]^{2}[\mathrm{Met}]}{\left(1+K_{1}\left[\mathrm{H}^{+}\right]\right)\left(\left[\mathrm{H}^{+}\right]^{2}+K_{4} K_{3} K_{2}^{2}[\mathrm{phen}]^{2}\right)},
$$


thereby implying negligible participation of the $1: 1$ complex of phenanthroline $\left(\mathrm{C}_{1}\right)$ in the reaction. The main reactive species in the reaction may therefore be regarded as $\left[\mathrm{Fe}(\text { phen })_{2}\left(\mathrm{H}_{2} \mathrm{O}\right)_{2}\right]^{3+}$ and the zwitterionic form of methionine $\left(\mathrm{Met}_{z}\right)$.

\section{Conclusion}

Methionine is a sulphur containing amino acid and it has three coordinating centres, oxygen, nitrogen and sulphur. The oxidation product of methionine depends on the nature of the oxidant. With some oxidants it is oxidized to the sulphoxide stage only, whereas with certain others it is oxidized to the sulphone stage. In all these oxidations electrophilic attack was reported to take place at the sulphur site (sulphur being more nucleophilic than nitrogen and oxygen). The protonated form of methionine is the reactive species in its oxidation by manganese(III) ${ }^{1}$ and bromate $^{2}$. But the oxidation of methionine by iron(III)-2,2'-bipyridyl ${ }^{3}$ or 1,10 -phenanthroline has been found to be extremely slow in acid media. However, the rate increases with decrease in $\left[\mathrm{H}^{+}\right]$thereby indicating that the zwitterionic form is far more reactive than the protonated form. This might be due to the ability of the zwitterionic form of methionine to coordinate through the negative carboxylic oxygen also, thereby stabilizing the transition state through the formation of a completely chelated iron(III) complex. While both iron(III)phenanthroline and iron(III) 2,2'-bipyridyl oxidize methionine to sulphoxide, oxidation with the former oxidant is much faster compared to the latter. This is because of the higher oxidation potential of the iron(III)-phenanthroline complex compared to the iron(III)-2,2'-bipyridyl. Hence the intimate mechanism of oxidation of methionine by iron(III) in presence of phenanthroline may be represented as in scheme 1 .
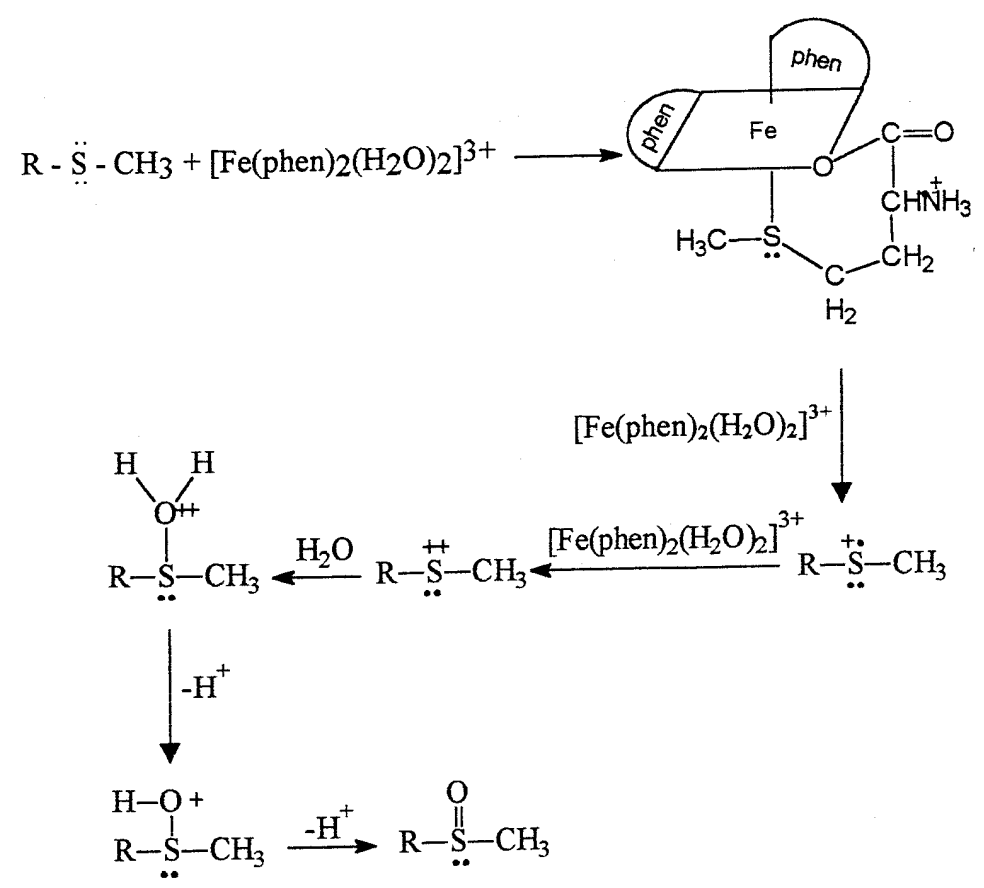

Scheme 1. 


\section{References}

1. Vani P and Rajeswari T R 1994 React. Kinet. Catal. Lett. 52175

2. Vani P, Rajeswari T R and Dikshitulu L S A 1995 J. Indian Chem. Soc. 72867

3. Rajeswari T R, Vani P and Dikshitulu L S A 1995 Transition Met. Chem. 20170

4. Gensch K H and Higuchi T 1967 J. Pharm. Sci. 56177

5. Milburn R M and Vosburgh W C 1955 J. Am. Chem. Soc. 771352

6. Goswami K B, Chandra G and Srivastava S N 1981 J. Indian Chem. Soc. 58252

7. Baxendale J H and Bridge N K 1955 J. Phys. Chem. 59783

8. Baxendale J H 1952 Advances in catalysis and related subjects (New York: Academic Press) vol. 4 , p. 64

9. David P C and de Mello P C 1973 Inorg. Chem. 122188

10. Brandt W W, Dwyer F P and Gyarfas E C 1954 Chem. Rev. 54959 